\title{
Coronaviruses Detected in Bats in Close Contact with Humans in Rwanda
}

\author{
Julius Nziza, ${ }^{1}$ Tracey Goldstein, ${ }^{2}$ Mike Cranfield, ${ }^{1}$ Paul Webala, ${ }^{3}$ Olivier Nsengimana, ${ }^{4}$ \\ Thierry Nyatanyi, ${ }^{5}$ Antoine Mudakikwa, ${ }^{6}$ Alexandre Tremeau-Bravard, ${ }^{2}$ \\ Dennis Byarugaba, ${ }^{7}$ Jean Claude Tumushime, ${ }^{1}$ Ivan Emil Mwikarago, ${ }^{8}$ \\ Isidore Gafarasi, ${ }^{9}$ Jonna Mazet, ${ }^{1,2}$ and Kirsten Gilardi ${ }^{1,2}$ \\ ${ }^{1}$ Gorilla Doctors, P.O. Box 115, Musanze, Rwanda \\ ${ }^{2}$ Karen C. Drayer Wildlife Health Center, One Health Institute, School of Veterinary Medicine, University of California Davis, Davis, CA \\ ${ }^{3}$ Department of Forestry and Wildlife Management, Maasai Mara University, P.O. Box 861, Narok 20500, Kenya \\ ${ }^{4}$ Rwanda Wildlife Conservation Association, P.O. Box 5427, Kigali, Rwanda \\ ${ }^{5}$ Department of Global Health and Social Medicine, School of Medicine, Harvard University, Boston \\ ${ }^{6}$ Rwanda Development Board, P.O. Box 6932, Kigali, Rwanda \\ ${ }^{7}$ Makerere University Walter Reed Project, College of Veterinary Medicine, Animal Resources and Biosecurity, Makerere University, Kampala, Uganda \\ ${ }^{8}$ National Reference Laboratory, Rwanda Biomedical Center, P.O. Box 83, Kigali, Rwanda \\ ${ }^{9}$ Rwanda Agriculture Board, P.O. Box 5016, Kigali, Rwanda
}

\begin{abstract}
Bats living in close contact with people in Rwanda were tested for evidence of infection with viruses of zoonotic potential. Mucosal swabs from 503 bats representing 17 species were sampled from 2010 to 2014 and screened by consensus PCR for 11 viral families. Samples were negative for all viral families except coronaviruses, which were detected in 27 bats belonging to eight species. Known coronaviruses detected included the betacorona viruses: Kenya bat coronaviruses, Eidolon bat coronavirus, and Bat coronavirus HKU9, as well as an alphacoronavirus, Chaerephon Bat coronavirus. Novel coronaviruses included two betacorona viruses clustering with SARS-CoV, a $2 \mathrm{~d}$ coronavirus, and an alphacoronavirus.
\end{abstract}

Keywords: Rwanda, Bats, Coronaviruses, Human-wildlife interfaces

\section{INTRODUCTION}

Bats are natural reservoirs for a number of pathogens of public health concern (Plowright et al. 2015; Shi 2013). For example, in Southeast Asia, Pteropus fruit bats are the natural reservoirs of the zoonotic paramyxoviruses Hendra and Nipah (Chua et al. 2000). In 2002-2003, an epidemic of severe acute respiratory syndrome (SARS) caused by a

Published online: December 6, 2019

Correspondence to: Julius Nziza, e-mail: nzizavet@gmail.com novel coronavirus (SARS-CoV) emerged in China (Drosten et al. 2003, Ksiazek et al. 2003), and bats were determined to be natural reservoirs and the possible source of the virus (Ge et al. 2013; Lau et al. 2010). In 2012, a pathogenic paramyxovirus, Sosuga virus, which caused severe illness in a patient following contact with bats in Uganda, was subsequently detected in Egyptian fruit bats (Rousettus aegyptiacus) (Amman et al. 2015). In Africa, Egyptian fruit bats (R. aegyptiacus) are reservoirs of Marburg virus (Towner et al. 2008), and antibodies against Zaire ebola virus have been detected in the same species (Pourrut et al. 2009), 
while antibodies against Bombali ebolavirus have been detected in Little free-tailed bat (Chaerephon pumilus), Angolan free-tailed bat (Mops condylurus) (Goldstein et al. 2018).

To assess the risk presented by human-bat contact, the USAID Emerging Pandemic Threats PREDICT project has been conducting viral surveillance in wildlife in more than 35 countries to detect viruses of zoonotic potential, including in Rwanda (https://ohi.vetmed.ucdavis.edu/prog rams-projects/predict-project).

Rwanda is continental Africa's most densely populated country (Butler 2004), and bats are frequently observed in/ around urban centers and adjacent to wildlife protected areas. Ecotourism centered on mountain gorillas in Volcanoes National Park also drives tourism to the nearby bat roosting "Musanze Caves" (Spenceley et al. 2010; Joachim 2013).

Between 2010 and 2014, biological sampling of bats was conducted at urban and rural sites in Rwanda characterized by an intense human-wildlife interface, including in and around Volcanoes National Park and the Musanze Caves. Anthropogenic activities around sampling sites were classified according to human livelihoods and activities, including ecotourism, crop farming, and national parks.

A total of 503 bats belonging to 17 species were captured at 25 sites (Fig. 1) following established PREDICT protocols for bat capture and sampling (PREDICT 2017) (Table 1). Following capture, bats were photographed, measured, and identified to species level as close as possible (Kingdon et al. 2013; Patterson and Webala 2012). Date, site name, season, apparent species, sex, age class (determined by the degree of epiphyseal-diaphyseal fusion) (Anthony 1988), reproductive status, and mass data were recorded. For handling and restraining larger fruit bats, light anesthesia was induced using inhalational isoflurane and oxygen (Fluriso ${ }^{\mathrm{TM}}$, Teva UK, Limited, Castleford, UK). Smaller fruit bats and insectivorous bats were physically restrained during sampling. All bats were released at the capture site within $3 \mathrm{~h}$ of capture.

Sampling for viral family screening included collection oral and rectal mucosal or fecal swabs. Swabs were placed into viral transport media (BD Universal Viral Transport ${ }^{\mathrm{TM}}$ medium, Becton, Dickinson and Co., Sparks, Maryland) and NucliSENS Lysis Buffer (bioMerieux SA ${ }^{\mathrm{TM}}$, Marcy l'Etoile, France) and stored in liquid nitrogen for transport and transfer to a $-80{ }^{\circ} \mathrm{C}$ freezer.

We extracted RNA from oral and rectal swab samples using the Qiamp Viral Mini kit ${ }^{\mathrm{TM}}$ (Qiagen Inc., Valencia,
CA) and reverse transcribed into cDNA using SuperScript III $^{\mathrm{TM}}$ (Invitrogen Corp, Carlsbad, CA). Primers targeting the housekeeping gene $\beta$-actin were used to ensure the presence of amplifiable nucleic acid in RNA extracts (Goldstein et al. 2004). Samples were screened by consensus PCR targeting conserved gene fragments using established assays know to detect corona (Quan et al. 2010; Watanabe et al. 2010), alpha (Sánchez-Seco et al. 2001), arena (Lozano et al. 1997), bunya (Briese et al. 2007), filo (Zhai et al. 2007), flavi (Moureau et al. 2007), hanta (Raboni et al. 2005), influenza (Anthony et al. 2012), paramyxo (Tong et al. 2008), lenti (Courgnaud et al. 2001), and rhabdo (Wray et al. 2016) viruses. Bands of the expected size were excised from 1\% agarose and purified using the Qiaquick kit (Qiagen Inc.). Purified PCR products were cloned (pCR4-TOPO vector; Invitrogen Corp.) and sequenced (ABI 3730 Capillary Electrophoresis Genetic Analyzer; Applied Biosystems, Inc., Foster City, CA). Sequences were analyzed and edited using Geneious (Version 6.0.3) and compared with known sequences in the Genbank database. Species identification of PCR-positive individuals was confirmed by DNA bar coding of the cytochrome b (Cytb) and cytochrome oxidase subunit 1 (CO1) mitochondrial genes (Townzen et al. 2008). Fisher's exact test was used to examine the association of viral positivity with age and season using STATA 13.0 software. The level of significance was set at $P \leq 0.05$ (Raymond and Rousset 1995).

No alpha, arena, bunya, filo, flavi, hanta, influenza, paramyxo, lenti, or rhabdo viruses were detected in oral or rectal swabs. Coronaviruses $(\mathrm{CoV})$ were detected in 27 (5.4\%) of the 503 bats sampled. Twenty-two of the 27 coronavirus positive bats belonged to three species: Strawcolored fruit bat (Eidolon helvum; 13 positives of 111 sampled, 11.7\%), Geoffroy's horseshoe bat (Rhinolophus clivosus; 5 of 24, 24.2\%), and Egyptian fruit bat (Rousettus aegyptiacus; 4 of 36, 11.1\%). Coronavirus positive bats were sampled at 11 different sites, including in the Musanze Caves (Table 1). Subadult bats were more likely to be positive for $\mathrm{CoV}$ than adults $(6 / 36$ vs. $21 / 429 ; P=0.04)$. No coronaviruses were detected in juvenile bats $(n=11)$. There were no observed differences between seasons (Dry/ Rainy; $3 / 90$ vs. $24 / 386 ; P=0.445$ ).

Coronavirus sequences were classified as belonging to different viral species according to established cutoffs and methods (Anthony et al. 2017b). We detected four known coronaviruses (Table 2) and four new coronaviruses (Table 3; Fig. 1). One of the new betacoronaviruses, Coronavirus PREDICT_CoV-43, was detected in Hipposideros 

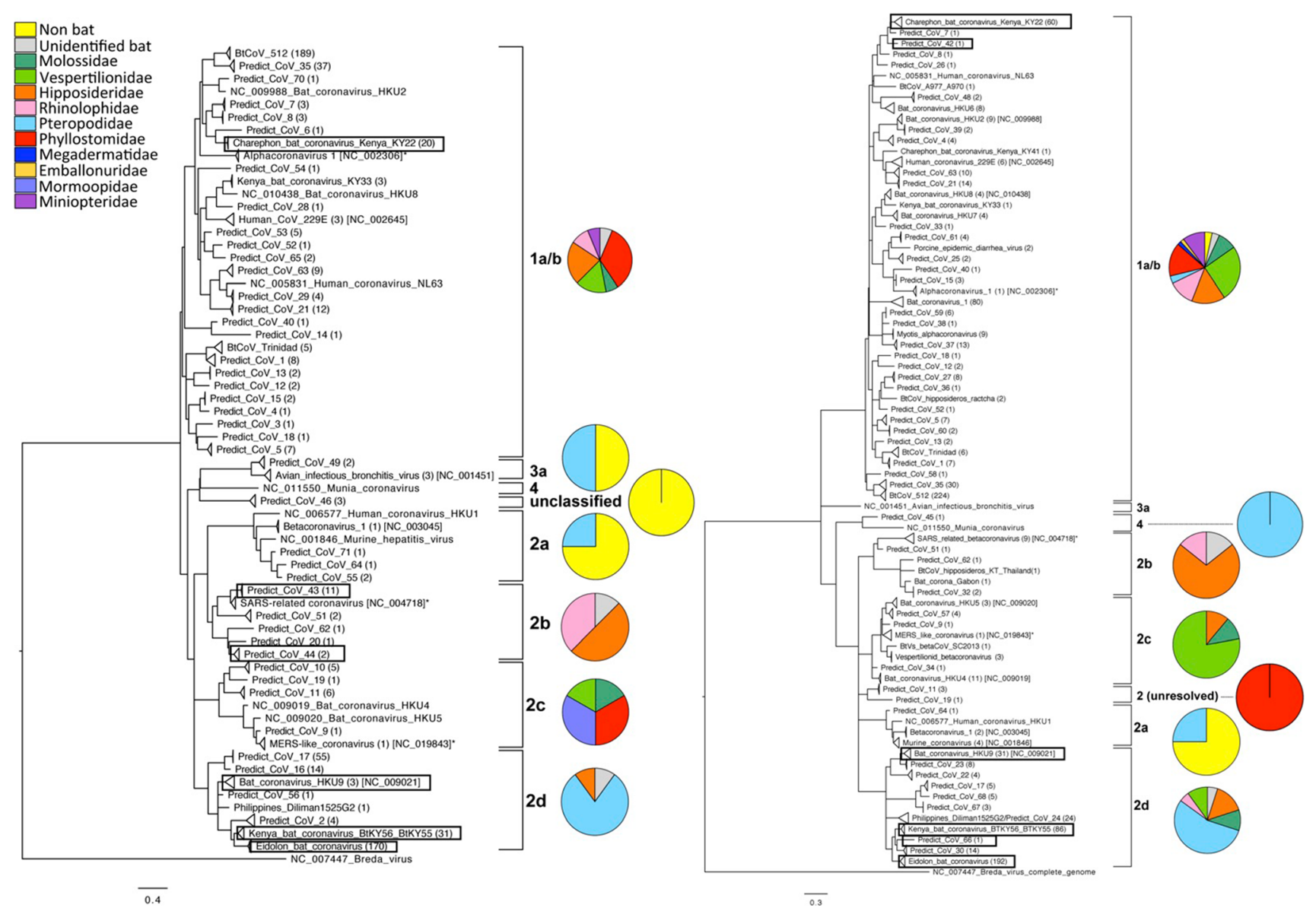

Figure 1. Coronaviruses phylogenetic analysis performed in Anthony et al. (2017b). Sequences are collapsed into clades, representing operating taxonomic units (sequences sharing equal or more than 90\%). The sequences included in this manuscript are indicated in the boxes.

ruber and $R$. clivosus bats co-roosting in bat tourism caves (Site 10; Fig. 1; Table 3). Comparison of the conserved polymerase gene fragment sequences to other known coronaviruses indicated that Coronavirus PREDICT_CoV43 clustered near the SARS-like coronaviruses but suggests it may be a distinct virus based on the conserved fragment sequence, as it showed only $84 \%$ nucleotide similarity to SARS-CoV (Genbank accession no. NC_009694). The second new betacoronavirus, PREDICT_CoV-44, was detected in two Hipposideros caffer bats trapped in Nyungwe National Park (Site No. 11) and in a R. clivosus bat in tourism caves at Site No. 10 (Fig. 2). Although the conserved sequence fragment also clustered with other betacoronaviruses, it was quite divergent, showing only $79 \%$ nucleotide similarity to others in the group.

The $2 \mathrm{~d}$ betacoronavirus, PREDICT_CoV-66, was detected in one Rousettus angolensis bat in Nyungwe National Park (Site 11; Fig. 2) and showed $84 \%$ nucleotide similarity to the closest recognized coronavirus, Kenya bat Coronavirus BtKY84 (Genbank accession no. GU65428) found previously in E. helvum. The only alphacoronavirus PREDICT_CoV-42 was detected in a R. clivosus bat in tourism caves (Site No. 10). This virus sequence showed only $85 \%$ nucleotide similarity to the closest recognized coronavirus, Kenya bat Coronavirus BtKY69 (Genbank accession no. GU65413), found previously in horseshoe bats (Rhinolophus species).

Phylogenetic analyses of complete genome sequences of coronaviruses from bats, humans, and other vertebrates suggest that bats may be the reservoir hosts from which all coronavirus lineages originated (Vijaykrishna et al. 2007; Anthony et al. 2017a), and several studies document the diversity of bat coronaviruses globally (Dominguez et al. 2007; Annan et al. 2013; Anthony et al. 2017b).

In this study, sequences representing two novel coronaviruses that clustered with the SARS-like coronaviruses 
Table 1. Bat Species Sampled at 25 Sites in Rwanda for 11 Viral Families, with Numbers and Percentages of Bats Testing Positive for CoV RNA.

\begin{tabular}{|c|c|c|c|c|c|c|}
\hline Site no.* & Species & Risk interface & Season & $\begin{array}{l}\text { Total tested (oral and } \\
\text { rectal swabs) }\end{array}$ & No. of positive & $\%$ Positive \\
\hline 2 & Epomophorus labiatus & Homestead & Rainy & 17 & 0 & 0 \\
\hline 25 & Mops condylurus & Homestead & Rainy & 78 & 0 & 0 \\
\hline 18 & M. condylurus & Homestead & Dry & 20 & 0 & 0 \\
\hline \multirow[t]{4}{*}{12} & Hipposideros caffer & Ecotourism site & Rainy & 15 & 1 & 7 \\
\hline & Rhinolophus clivosus & Ecotourism site & Rainy & 19 & 4 & 21 \\
\hline & Rousettus aegyptiacus & Ecotourism site & Rainy & 9 & 0 & 0 \\
\hline & Otomops martiensseni & Ecotourism site & Rainy & 1 & 0 & 0 \\
\hline \multirow[t]{4}{*}{7} & R. clivosus & Ecotourism site & Rainy & 5 & 1 & 20 \\
\hline & R. aegyptiacus & Ecotourism site & Rainy & 13 & 0 & 0 \\
\hline & Hipposideros ruber & Ecotourism site & Rainy & 2 & 0 & 0 \\
\hline & Nycteris hispida & Ecotourism site & Rainy & 1 & 0 & 0 \\
\hline 3 & Eidolon helvum & Ecotourism site & Rainy & 53 & 4 & 7,5 \\
\hline 16 & E. helvum & Homestead & Dry & 15 & 0 & 0 \\
\hline 8 & E. helvum & Homestead & Rainy & 9 & 2 & 22 \\
\hline 5 & E. helvum & Crop farming & Rainy & 9 & 6 & 67 \\
\hline 6 & R. Aegyptiacus & Ecotourism site & Rainy & 9 & 2 & 22 \\
\hline \multirow[t]{3}{*}{11} & Neoromicia tenuipinnis & National park & Rainy & 5 & 0 & 0 \\
\hline & Myonicteris angolensis & National park & Rainy & 6 & 1 & 17 \\
\hline & H. caffer & National park & Rainy & 1 & 0 & 0 \\
\hline \multirow[t]{2}{*}{23} & Stenonycteris lanosus & National park & Rainy & 1 & 0 & 0 \\
\hline & M. angolensis & National park & Rainy & 23 & 0 & 0 \\
\hline \multirow[t]{3}{*}{10} & Epomophorus labiatus & Crop farming & Rainy & 6 & 0 & 0 \\
\hline & S. lanosus & Crop farming & Rainy & 5 & 0 & 0 \\
\hline & R. Aegyptiacus & Crop farming & Dry & 5 & 2 & 40 \\
\hline 4 & E. helvum & Ecotourism site & Rainy & 5 & 1 & 20 \\
\hline \multirow[t]{3}{*}{22} & N. hispida & Fishing area & Rainy & 1 & 0 & 0 \\
\hline & E. Labiatus & Fishing area & Rainy & 3 & 0 & 0 \\
\hline & Lavia frons & Fishing area & Rainy & 1 & 0 & 0 \\
\hline \multirow[t]{2}{*}{21} & N. hispida & Ecotourism site & Rainy & 1 & 0 & 0 \\
\hline & E. Labiatus & Ecotourism site & Rainy & 2 & 0 & 0 \\
\hline 24 & M. condylurus & Homestead & Rainy & 20 & 0 & 0 \\
\hline \multirow[t]{2}{*}{20} & Chaerephon pumilus & National park & Rainy & 8 & 0 & 0 \\
\hline & M. condylurus & National park & Rainy & 12 & 0 & 0 \\
\hline 9 & E. Labiatus & Homestead & Rainy & 5 & 0 & 0 \\
\hline \multirow[t]{3}{*}{13} & E. Labiatus & Ecotourism site & Rainy & 35 & 0 & 0 \\
\hline & N. tenuipinnis & Ecotourism site & Rainy & 1 & 0 & 0 \\
\hline & Neoromicia cf. zuluensis $\backslash$ & Ecotourism site & Rainy & 2 & 0 & 0 \\
\hline 17 & E. helvum & Homestead & Rainy & 20 & 0 & 0 \\
\hline \multirow[t]{3}{*}{19} & Scotophilus viridis & Homestead & Rainy & 4 & 0 & 0 \\
\hline & C. pumilus & Homestead & Rainy & 3 & 1 & 33 \\
\hline & E. Labiatus & Homestead & Rainy & 18 & 0 & 0 \\
\hline \multirow[t]{2}{*}{15} & E. Labiatus & Homestead & Rainy & 2 & 0 & 0 \\
\hline & S. viridis & Homestead & Rainy & 1 & 0 & 0 \\
\hline
\end{tabular}


Table 1. continued

\begin{tabular}{|c|c|c|c|c|c|c|}
\hline Site no.* & Species & Risk interface & Season & $\begin{array}{l}\text { Total tested (oral and } \\
\text { rectal swabs) }\end{array}$ & No. of positive & \% Positive \\
\hline \multirow[t]{3}{*}{1} & M. Angolensis & Homestead & Rainy & 16 & 0 & 0 \\
\hline & E. Labiatus & Homestead & Rainy & 9 & 1 & 11 \\
\hline & S. viridis & Homestead & Rainy & 1 & 0 & 0 \\
\hline 14 & N. hispida & Homestead & Dry & 6 & 0 & 0 \\
\hline Total & & & & 503 & 27 & 54 \\
\hline
\end{tabular}

^Bats sampling sites can be visualized in Figure 2 by site number.

Table 2. Known Coronaviruses Detected in Bats by Species and Specimen Type.

\begin{tabular}{|c|c|c|c|c|c|c|c|}
\hline Bat species & $\begin{array}{l}\text { c-PCR } \\
\text { positive }\end{array}$ & $\begin{array}{l}\text { Sample } \\
\text { tested }\end{array}$ & $\begin{array}{l}\text { Year of collec- } \\
\text { tion/ } \\
\text { season }\end{array}$ & $\begin{array}{l}\text { Site } \\
\text { no }\end{array}$ & $\begin{array}{l}\text { Risk } \\
\quad \text { interface }\end{array}$ & Virus name & $\begin{array}{l}\text { Genbank } \\
\text { No. }\end{array}$ \\
\hline Epomophorus labiatus & 1 & $\begin{array}{l}\text { Rectal } \\
\text { swab }\end{array}$ & 2013/Rainy & 1 & Home stead & $\begin{array}{l}\text { Strain of Kenya bat coron- } \\
\text { avirus/BtKY56/BtKY55 }\end{array}$ & KX285830 \\
\hline Chaerephon pumilus & 1 & $\begin{array}{l}\text { Rectal } \\
\text { swab }\end{array}$ & 2013/Rainy & 6 & $\begin{array}{l}\text { Ecotourism } \\
\text { site }\end{array}$ & $\begin{array}{l}\text { Strain of Chaerephon } \\
\text { bat/coronavirus/Kenya/ } \\
\text { KY22/2006 }\end{array}$ & KX285828 \\
\hline Eidolon helvum & 4 & $\begin{array}{l}\text { Rectal } \\
\text { swab }\end{array}$ & 2012/Rainy & 3 & $\begin{array}{l}\text { Ecotourism } \\
\text { site }\end{array}$ & $\begin{array}{c}\text { Strain of Eidolon bat coron- } \\
\text { avirus/Kenya/KY24/2006 }\end{array}$ & KX285106 \\
\hline Eidolon helvum & 1 & $\begin{array}{l}\text { Rectal } \\
\text { swab }\end{array}$ & 2012/Rainy & 4 & $\begin{array}{l}\text { Ecotourism } \\
\text { site }\end{array}$ & $\begin{array}{c}\text { Strain of Eidolon bat coron- } \\
\text { avirus/Kenya/KY24/2006 }\end{array}$ & KX285107 \\
\hline Eidolon helvum & 6 & $\begin{array}{r}\text { Rectal } \\
\text { swab }\end{array}$ & 2013/Dry & 5 & $\begin{array}{l}\text { Crop farm- } \\
\text { ing }\end{array}$ & $\begin{array}{l}\text { Strain of Eidolon bat coron- } \\
\text { avirus/Kenya/KY24/2006 }\end{array}$ & KX285108 \\
\hline Rousettus aegyptiacus & 2 & $\begin{array}{r}\text { Rectal } \\
\text { swab }\end{array}$ & 2013/Rainy & 6 & $\begin{array}{l}\text { Ecotourism } \\
\text { site }\end{array}$ & $\begin{array}{l}\text { Strain of Bat coronavirus } \\
\text { HKU9 }\end{array}$ & KX286259 \\
\hline Rousettus aegyptiacus & 2 & $\begin{array}{r}\text { Rectal } \\
\text { swab }\end{array}$ & 2013/Rainy & 1 & Home stead & $\begin{array}{c}\text { Strain of Kenya bat coron- } \\
\text { avirus/BtKY56/BtKY55 }\end{array}$ & KX285819 \\
\hline \multirow[t]{2}{*}{ Eidolon helvum } & 2 & $\begin{array}{r}\text { Rectal } \\
\text { swab }\end{array}$ & 2012/Rainy & 3 & $\begin{array}{l}\text { Ecotourism } \\
\text { site }\end{array}$ & $\begin{array}{c}\text { Strain of Eidolon bat coron- } \\
\text { avirus/Kenya/KY24/2006 }\end{array}$ & KX285822 \\
\hline & 19 & & & & & & \\
\hline
\end{tabular}

were detected in bat tourism caves and other sites where people and bats come into close contact in Rwanda. One virus (PREDICT CoV-43) was detected in both Sundevall's roundleaf bat (H. ruber) and Geoffrey's horseshoe bat ( $R$. clivosus) that were co-roosting in the Musanze Caves (Site No. 10). The high sequence similarity of the viral fragment detected in both bat species suggests that this virus may have the ability to be maintained in more than one host or that cross-species transmission may occur. Studies have found that viral sharing and cross-species transmission may be important factors that contribute to emergence of novel coronaviruses and recombination of bat coronaviruses (Lau et al. 2010; Johnson et al. 2015).

While the known coronaviruses detected in this study have been identified in other geographical areas and in different bat species (Tao et al. 2012; Drexler et al. 2010), we report their first detection in Rwanda. The bat coronavirus HKU9 was previously detected in Rousettus leschenaulti bats in China (Tang et al. 2006), and now a strain of this virus has been detected in bats in Rwanda. Similarly, 
Table 3. Novel Coronaviruses Detected in Bats by Species and Specimen Type.

\begin{tabular}{|c|c|c|c|c|c|c|c|}
\hline Bat species & $\begin{array}{l}\text { c-PCR } \\
\text { positive }\end{array}$ & Sample tested & $\begin{array}{l}\text { Year of collection/ } \\
\text { season }\end{array}$ & Site no. & Risk interface & Virus name & Genbank no. \\
\hline Rhinolophus clivosus & 1 & Oral swab & 2011/Rainy & 12 & Ecotourism sites & PREDICT_CoV-43 & KX285821 \\
\hline Rousettus angolensis & 1 & Rectal swab & 2013/Rainy & 11 & National park & PREDICT_CoV-66 & KX285426 \\
\hline Hipposideros caffer & 1 & Rectal swab & 2011/Rainy & 11 & National park & PREDICT_CoV-44 & KX285826 \\
\hline Rhinolophus clivosus & 1 & Rectal swab & 2013/Rainy & 11 & National park & PREDICT_CoV-44 & KX286327 \\
\hline Hipposideros ruber & 1 & Rectal swab & 2013/Rainy & 10 & Crop farming & PREDICT_CoV-43 & KX286324 \\
\hline Rhinolophus clivosus & 2 & Rectal swab & 2011/Rainy & 12 & Ecotourism site & PREDICT_CoV-43 & KX286325 \\
\hline \multirow[t]{2}{*}{ Rhinolophus clivosus } & 1 & Rectal swab & 2011/Rainy & 12 & Ecotourism site & PREDICT_CoV-42 & KX285111 \\
\hline & 8 & & & & & & \\
\hline
\end{tabular}

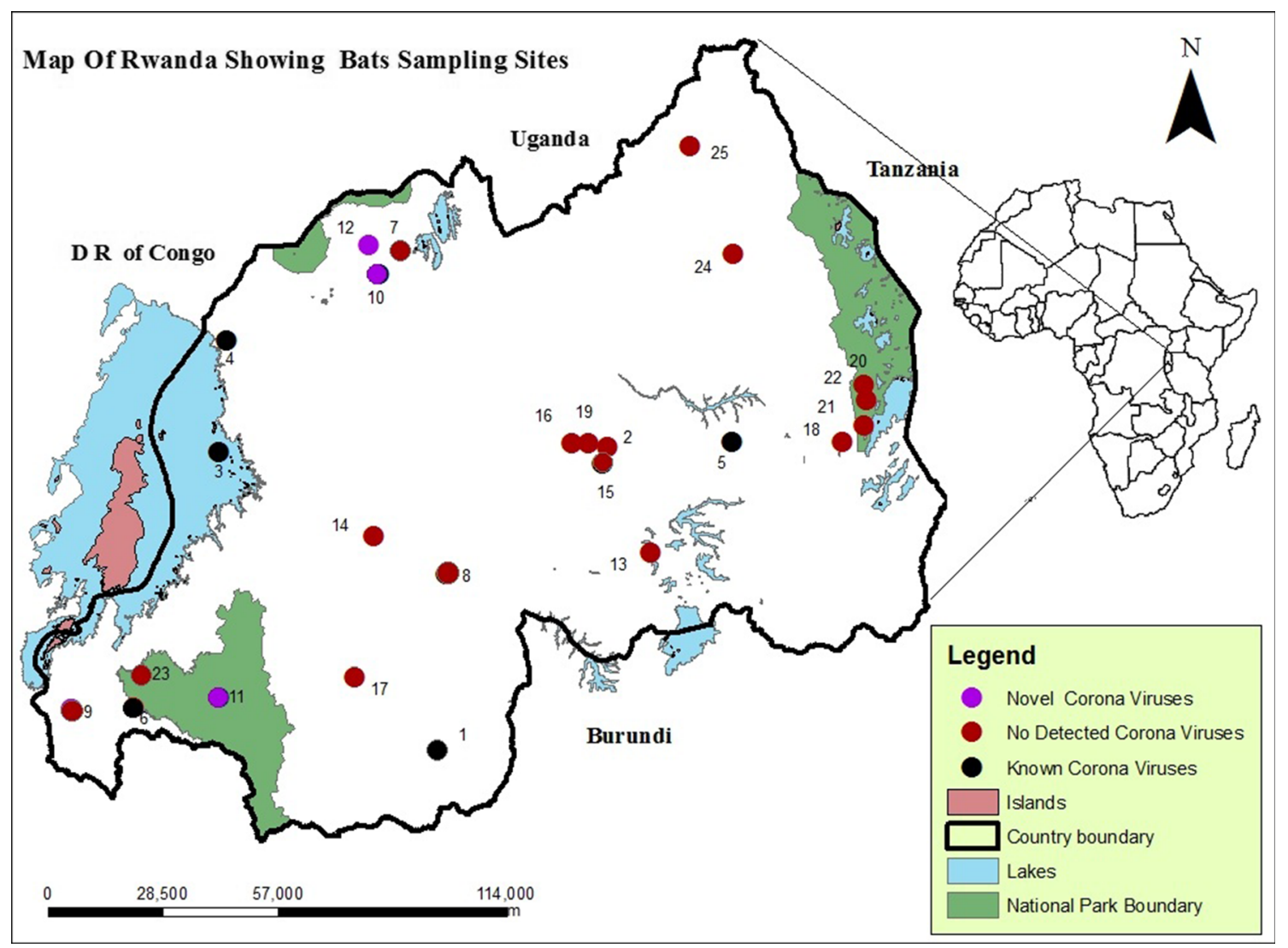

Figure 2. Map of Rwanda showing the bats sampling sites for corona viral surveillance during the study.

Kenya bat coronavirus/BtKY56/BtKY55 in R. aegyptiacus, Chaerephon bat coronavirus/Kenya/KY22/2006 in Chaerephon pumilus, and Eidolon bat coronavirus/Kenya/KY24/ 2006 in Eidolon helvum were first detected in Kenya in 2006 (Tao et al. 2012). We report the presence of these viruses in these same bat species in Rwanda, indicating a wider geographic distribution of these viruses in Eastern Africa, likely due to the widespread distribution of their bat hosts (Drexler et al. 2010; Gloza-Rausch et al. 2008).

In conclusion, bats in Rwanda carry novel and known coronaviruses, a family of viruses from which novel viruses have caused human pandemics. However, bats play important ecological roles and their elimination as a control measure is not recommended or warranted. We rec- 
ommend additional surveillance and longitudinal studies to further understand the ecology of bat coronaviruses and the extent of human-bat interactions to identify strategies for public health protection and bat conservation.

\section{ACKNOWLEDGMENTS}

We thank the government of Rwanda for permission to conduct this work. This study was made possible by the generous support of the American people through the United States Agency for International Development (USAID) Emerging Pandemic Threats PREDICT project (cooperative agreement number GHN-A-OO-09-00010$00)$. The results from the study do not indicate the opinion of the United States of America government. Sampling was conducted under a University of California, Davis Animal Care and Use Committee approved protocol (UC Davis IACUC Protocol No. 16048). We thank also the One Health Institute Laboratory at University of California, Davis for viral sequencing, the RAB Wildlife Virology laboratory in Kigali for raw sample processing and storage, and Makerere University Walter Reed Project for viral family testing.

\section{REFERENCES}

Amman BR, Albariño CG, Bird BH, Nyakarahuka L, Sealy TK, Balinandi S, Schuh AJ, Campbell SM, Ströher U, Jones ME, Vodzack ME, Reeder DM, Kaboyo W, Nictal ST, Towner JS (2015) A recently discovered pathogenic paramyxovirus, Sosuga virus, is present in Rousettus aegyptiacus fruit bats at multiple locations in Uganda. Journal of Wildlife Diseases 51(3):774-779

Annan A, Baldwin HJ, Corman VM, Klose SM, Owusu M, Nkrumah EE, Badu EK, Anti P, Agbenyega O, Meyer B, Oppong S, Sarkodie YA, Kalko EKV, Lina PHC, Godlerska EV, Reusken C, Seebens A, Gloza-Rausch F, Vallo P, Tschapka M, Drosten C, Drexler JF (2013) Human betacoronavirus 2c EMC/2012-related viruses in bats, Ghana and Europe. Emerging Infectious Diseases 19(3):456

Anthony ELP (1988) Age determination in bats. In: Kunz TH, (editor), Washington, DC: Smithsonian Institution Press, pp $47-58$

Anthony SJ, Gilardi K, Menachery VD, Goldstein T, Ssebide B, Mbabazi R, Navarrete-Macias I, Liang E, Wells H, Hicks A, Petrosov A, Byarugaba DK, Debbink K, Dinnon KH, Scobey T, Randell SH, Yount BL, Cranfield M, Johnson CK, Baric RS, Lipkin WI, Mazet JAK (2017) Further evidence for bats as the evolutionary source of middle east respiratory syndrome coronavirus. MBio 8(2):e00373-17

Anthony SJ, Johnson CK, Greig DJ, Kramer S, Che X, Wells H, Hicks AL, Joly DO, Wolfe ND, Daszak P, Karesh W, Lipkin WI, Morse SSPREDICT ConsortiumMazet JAK, Goldstein T (2017)
Global patterns in coronavirus diversity. Virus Evolution 3(1):vex012

Anthony SJ, Leger JS, Pugliares K, Ip HS, Chan JM, Carpenter ZW, Navarrete-Macias I, Sanchez-Leon M, Saliki JT, Pedersen J, Karesh W, Daszak P, Rabadan R, Rowles T, Lipkin WI (2012) Emergence of fatal avian influenza in New England harbor seals. MBio 3(4):e00166-12

Briese T, Kapoor V, Lipkin WI (2007) Natural M-segment reassortment in Potosi and Main Drain viruses: implications for the evolution of orthobunyaviruses. Archives of Virology 152(12):2237-2247

Butler CD (2004) Human carrying capacity and human health. PLoS Med 1(3):e55

Chua KB, Bellini WJ, Rota PA, Harcourt BH, Tamin A, Lam SK, Ksiazek TG, Rollin PE, Zaki SR, Shieh WJ, Goldsmith CS, Goubler DV, Roehrig JT, Eaton B, Gould AR, Olson J, Field H, Daniels P, Ling AE, Peters CJ, Anderson LJ, Mahy BWJ (2000) Nipah virus: a recently emergent deadly paramyxovirus. Science 288(5470):1432-1435

Courgnaud V, Pourrut X, Bibollet-Ruche F, Mpoudi-Ngole E, Bourgeois A, Delaporte E, Peeters M (2001) Characterization of a novel simian immunodeficiency virus from guereza colobus monkeys (Colobus guereza) in Cameroon: a new lineage in the nonhuman primate lentivirus family. Journal of Virology 75(2):857-866

Dominguez SR, O’Shea TJ, Oko LM, Holmes KV (2007) Detection of group 1 coronaviruses in bats in North America. Emerging Infectious Diseases 13(9):1295

Drexler JF, Gloza-Rausch F, Glende J, Corman VM, Muth D, Goettsche M, Seebens A, Niedrig M, Pfefferle S, Yordanov S, Zhelyazkov L, Hermanns U, Vallo P, Lukasher A, Muller MA, Deng H, Herrler G, Drosten C (2010) Genomic characterization of severe acute respiratory syndrome-related coronavirus in European bats and classification of coronaviruses based on partial RNA-dependent RNA polymerase gene sequences. Journal of Virology 84(21):11336-11349

Drosten C, Günther S, Preiser W, Van Der Werf S, Brodt HR, Becker S, Rabenau H, Panning M, Kolesnikova L, Fouchier RA, Berger A, Burguiere A-M, Cinatl J, Eickmann M, Escrion N, Grywna K, Kramme S, Manuguerra J-C, Muller S, Rickerts V, Stuermer M, Vieth S, Klenk H-D, Osterhans AD, Schmitz H, Doerr HM (2003) Identification of a novel coronavirus in patients with severe acute respiratory syndrome. New England Journal of Medicine 348(20):1967-1976

Ge XY, Li JL, Yang XL, Chmura AA, Zhu G, Epstein JH, Mazet JK, Hu B, Zhang W, Peng C, Zhang YJ, Luo C-M, Tan B, Wang N, Zhu Y, Crameri G, Zhang S-Y, Wang L-F, Daszak P, Zheng L-S (2013) Isolation and characterization of a bat SARS-like coronavirus that uses the ACE2 receptor. Nature 503(7477):535-538

Gloza-Rausch F, Ipsen A, Seebens A, Göttsche M, Panning M, Drexler JF, Petersen N, Annan A, Grywna K, Müller M, Pfefferle S, Drosten C (2008) Detection and prevalence patterns of group I coronaviruses in bats, northern Germany. Emerging Infectious Diseases 14(4):626

Goldstein T, Anthony SJ, Gbakima A, Bird BH, Bangura J, Tremeau-Bravard A, Belaganahalli MN, Wells HL, Dhanota JK, Liang E, Grodus M, Jangra RK, DeJesus VA, Lasso G, Smith BR, Jambai A, Kamara BO, Kamara S, Bangura W, Monagin C, Shapira S, Johnson CK, Saylors K, Rubin EM, Chandran K, Lipkin WI, Mazet JAK (2018) The discovery of Bombali virus adds further support for bats as hosts of ebolaviruses. Nature Microbiology 3(10):1084 
Goldstein T, Mazet JAK, Gulland FMD, Rowles T, Harvey JT, Allen SG, King DP, Aldridge BM, Stott JL (2004) The transmission of Phocine herpesvirus-1 in rehabilitating and freeranging Pacific harbor seals (Phoca vitulina) in California. Veterinary Microbiology 103:131-141

Joachim N (2013) Investigating the challenges of promoting dark tourism in Rwanda. GRIN Verlag

Johnson CK, Hitchens PL, Evans TS, Goldstein T, Thomas K, Clements A, Joly DO, Wolfe ND, Daszak P, Karesh WB, Mazet JK (2015) Spillover and pandemic properties of zoonotic viruses with high host plasticity. Scientific Reports 5:14830

Kingdon J, Happold D, Butynski T, Hoffmann M, Happold M, Kalina J (2013) Mammals of Africa, London: A\&C Black

Ksiazek TG, Erdman D, Goldsmith CS, Zaki SR, Peret T, Emery S, Tong S, Urbani C, Comer JA, Lim W, Rollin PE, Dowell SF, Ling A-E, Humphrey CD, Shieh W-J, Guarner J, Paddock CD, Rota P, Fields B, Derisi J, Yang J-S, Cox N, Hughes JM, LeDuc JW, Bellini WJ, Anderson LJ (2003) A novel coronavirus associated with severe acute respiratory syndrome. New England Journal of Medicine 348(20):1953-1966

Lau SK, Li KS, Huang Y, Shek CT, Tse H, Wang M, Choi GK, Xu H, Lam CS, Guo R, Chan KH, Jeng B-J, Woo PCY, Yuen K-Y (2010) Ecoepidemiology and complete genome comparison of different strains of severe acute respiratory syndrome-related Rhinolophus bat coronavirus in China reveal bats as a reservoir for acute, self-limiting infection that allows recombination events. Journal of Virology 84(6):2808-2819

Lozano ME, Posik DM, Albarino CG, Schujman G, Ghiringhelli PD, Calderon G, Sabattini M, Romanowski V (1997) Characterization of arenaviruses using a family-specific primer set for RT-PCR amplification and RFLP analysis: its potential use for detection of uncharacterized arenaviruses. Virus Research 49(1):79-89

Moureau G, Temmam S, Gonzalez JP, Charrel RN, Grard G, De Lamballerie X (2007) A real-time RT-PCR method for the universal detection and identification of flaviviruses. VectorBorne and Zoonotic Diseases 7(4):467-478

Patterson BD, Webala PW (2012) Keys to the bats (Mammalia: Chiroptera) of east Africa. Fieldiana Life and Earth Sciences 2012:1-60

Plowright RK, Eby P, Hudson PJ, Smith IL, Westcott D, Bryden WL, Middleton D, Reid PA, McFarlane RA, Martin G, Tabor GM, Skerratt LF, Anderson DL, Crameri G, Quammen D, Jordan D, Freeman P, Wang L-F, Epstein JH, Marsh GA, Kung NY, McCallum H (2015) Ecological dynamics of emerging bat virus spillover. Proceedings of the Royal Society B: Biological Sciences 282(1798):20142124

Pourrut X, Souris M, Towner JS, Rollin PE, Nichol ST, Gonzalez JP, Leroy E (2009) Large serological survey showing co-circulation of Ebola and Marburg viruses in Gabonese bat populations, and a high seroprevalence of both viruses in Rousettus aegyptiacus. BMC Infectious Diseases 9(1):159

PREDICT (2017) https://www2.vetmed.ucdavis.edu/ohi/local_res ources/pdfs/guides/predict-sop-bat-sampling-2017.pdf

Quan PL, Firth C, Street C, Henriquez JA, Petrosov A, Tashmukhamedova A, Hutchison SK, Egholm M, Osinubi MO, Niezgoda M, Ogunkoya AB, Briese T, Rupprecht CE, Lipkin WI (2010) Identification of a severe acute respiratory syndrome coronavirus-like virus in a leaf-nosed bat in Nigeria. MBio 1(4):e00208-10

Raboni SM, Probst CM, Bordignon J, Zeferino A, dos Santos CND (2005) Hantaviruses in Central South America: phylogenetic analysis of the S segment from HPS cases in Paraná, Brazil. Journal of Medical Virology 76(4):553-562

Raymond M, Rousset F (1995) An exact test for population differentiation. Evolution 49(6):1280-1283

Sánchez-Seco MP, Rosario D, Quiroz E, Guzmán G, Tenorio A (2001) A generic nested-RT-PCR followed by sequencing for detection and identification of members of the alphavirus genus. Journal of Virological Methods 95(1-2):153-161

Shi Z (2013) Emerging infectious diseases associated with bat viruses. Science China Life Sciences 56(8):678-682

Spenceley A, Habyalimana S, Tusabe R, Mariza D (2010) Benefits to the poor from gorilla tourism in Rwanda. Development Southern Africa 27(5):647-662

Tang XC, Zhang JX, Zhang SY, Wang P, Fan XH, Li LF, Li G, Dong BQ, Liu W, Cheung CL, Xu KM, Song WJ, Vijaykrishna D, Poon LL, Peiris JSM, Smith GJD, Chen H, Guan Y (2006) Prevalence and genetic diversity of coronaviruses in bats from China. Journal of Virology 80(15):7481-7490

Tao Y, Tang K, Shi M, Conrardy C, Li KS, Lau SK, Anderson LJ, Tong S (2012) Genomic characterization of seven distinct bat coronaviruses in Kenya. Virus Research 167(1):67-73

Tong S, Chern SWW, Li Y, Pallansch MA, Anderson LJ (2008) Sensitive and broadly reactive reverse transcription-PCR assays to detect novel paramyxoviruses. Journal of Clinical Microbiology 46(8):2652-2658

Towner JS, Sealy TK, Khristova ML, Albariño CG, Conlan S, Reeder SA, Quan PL, Lipkin WI, Downing R, Tappero JW, Okware S, Lutwama J, Bakamutumaho B, Kayiwa J, Corner JA, Rollin PE, Ksiazek TG, Nichol ST (2008) Newly discovered ebola virus associated with hemorrhagic fever outbreak in Uganda. PLoS Pathog 4(11):e1000212

Townzen JS, Brower AVZ, Judd DD (2008) Identification of mosquito blood meals using mitochondrial cytochrome oxidase subunit I and cytochrome $\mathrm{b}$ gene sequences. Medical and Veterinary Entomology 22(4):386-393

Vijaykrishna D, Smith GJD, Zhang JX, Peiris JSM, Chen H, Guan $\mathrm{Y}$ (2007) Evolutionary insights into the ecology of coronaviruses. Journal of Virology 81(8):4012-4020

Watanabe S, Masangkay JS, Nagata N, Morikawa S, Mizutani T, Fukushi S, Alviola P, Omatsu T, Ueda N, Iha K, Taniguchi S, Fujii H, Tsnda S, Endoh M, Kato K, Tohya Y, Kyuwa S, Yoshikawa Y, Akashi H (2010) Bat coronaviruses and experimental infection of bats, the Philippines. Emerging Infectious Diseases 16(8):1217

Wray AK, Olival KJ, Morán D, Lopez MR, Alvarez D, NavarreteMacias I, Liang E, Simmons NB, Lipkin WI, Daszak P, Anthony SJ (2016) Viral diversity, prey preference, and Bartonella prevalence in Desmodus rotundus in Guatemala. EcoHealth 13(4):761-774

Zhai J, Palacios G, Towner JS, Jabado O, Kapoor V, Venter M, Grolla A, Briese T, Paweska J, Swanepoel R, Feldmann H, Nichol ST, Lipkin WI (2007) Rapid molecular strategy for filovirus detection and characterization. Journal of Clinical Microbiology 45(1):224-226 